\title{
PENINGKATAN KINERJA IPAL LUMPUR AKTIF DENGAN PENAMBAHAN UNIT BIOFILTER (STUDI KASUS IPAL PASARAYA BLOK M, KAPASITAS $420 \mathrm{M}^{3} /$ HARI)
}

\author{
Performance Improvement Of Activated Sludge WWTP With Addition Of Biofilter Unit \\ (Case Study Of WWTP Pasaraya Blok M, Capacity $420 \mathrm{M}^{3} /$ Day)
}

\author{
Oleh: \\ Ikbal \\ Pusat Tekologi Lingkungan, BPPT
}

\begin{abstract}
Abstrak
Pemilihan sistem IPAL sangat ditentukan oleh karakteristik air limbah yang akan diolah. Sistem IPAL yang salah, disamping kualitas air olahan nantinya sulit memenuhi baku mutu yang dipersyaratkan, juga menyebabkan biaya operasional IPAL menjadi tinggi. Penambahan unit biofilter pada IPAL sistem lumpur aktif yang dimiliki Pasaraya Blok M, memberikan hasil yang sangat menggembirakan. Selama lebih dari 1 tahun IPAL beroperasi, kinerja IPAL selalu baik. Konsentrasi $\mathrm{BOD}, \mathrm{COD}$ dan $\mathrm{KMnO}_{4}$ dalam air limbah dapat diturunkan sampai di atas 90\%, demikian juga polutan TSS dapat dikurangi sampai 90\%. Konsentrasi semua polutan dalam air olahan jauh di bawah baku mutu yang ditetapkan, sehingga tidak mencemari lingkungan. IPAL Pasaraya Blok M sudah memiliki Sertifikat Izin Pembuangan Limbah Cair (IPLC), sebagai syarat diizinkannya unit usaha membuang air olahan ke badan penerima air. Pasaraya Blok M juga melakukan swapantau operasional IPAL dan analisa berkala ke laboratorium terakreditasi.
\end{abstract}

Kata kunci : air limbah domestik, instalasi pengolahan air limbah, polutan organik, lumpur aktif, biofilter, efisiensi pengolahan.

\begin{abstract}
WWTP system selection is determined by the characteristics of the waste water. Wrong WWTP system will cause quality of treated water difficult to meet the Quality Standard and also lead to high operating costs. Added Biofilter unit to Pasaraya Blok M WWTP system, provide very encouraging result. For more than one year, WWTP operation always in good performance. The concentration of BOD, COD and $\mathrm{KMnO} 4$ can be derived more than $90 \%$, as well as TSS can be reduced over $90 \%$. The concentration of all pollutants in treated water far below the government quality standards, so it's not polluted to the environment. WWTP Pasaraya Blok M already has Liquid Waste Disposal License Certificate (IPLC), as a legal statement or certificate that allowed them to dispose of treatment water into the water body. Pasaraya Blok M also performs self-monitoring for operational of WWTP and periodic analysis to an accredited laboratory.
\end{abstract}

Keywords : domestic waste water, waste water treatment plants, organic pollutants, activated sludge, biofilter, treatment efficiency

\section{PENDAHULUAN}

\subsection{Latar Belakang}

Saat ini, masalah pencemaran lingkungan oleh air limbah di kota-kota besar di Indonesia cukup mengkhawatirkan. Beban polutan yang masuk ke badan penerima air seperti sungai, situ dan danau sudah melampaui daya dukung lingkungan sehingga alam sudah tidak mampu lagi melakukan pemulihan diri sendiri (self furification). Dampak dari pencemaran ini antara lain adalah turunnya kualitas air pada badan penerima air dan terancamnya kehidupan biota diperairan. Lebih dari itu, juga telah menimbulkan kematian masal biota perairan secara tiba-tiba, seperti yang pernah terjadi di Teluk Jakarta beberapa waktu yang lalu (Ikbal, 2013).

Menurun kajian yang dilakukan oleh Japan International Cooperation Agency (JICA), dari 
jumlah air limbah yang mengalir masuk ke badan air atau sungai-sungai di Jakarta, sekitar $80 \%$ adalah air limbah domestik dan hanya sekitar $20 \%$ dari kegiatan lain seperti indusri manufakturing. Sebagian besar air limbah domestik ini belum diolah sebagaimana mestinya. Besarnya jumlah air limbah domestik ini, menjadi penyebab utama tercemarnya sungai di kota-kota besar. Air limbah domestik adalah air limbah yang dihasilkan dari kegaitan manusia sehari-hari di rumah atau di tempat beraktifitas lainnya, yaitu air limbah dari toilet, dapur, pencucian pakaian dan dari kamar mandi. Penghasil utama air limbah domestik adalah kawasan pemukiman, kegiatan hotel, kantor, pusat perbelanjaan dan rumah sakit. Air limbah domestik, meskipun konsentrasi polutan yang dikandungnya tidak terlalu tinggi bila dibandingkan dengan air limbah industri, tetapi karena jumlahnya sangat banyak dan merata pada semua tempat, maka potensi pencemaran yang ditimbulkan air limbah ini juga sangat besar. Di kota-kota besar seperti Jakarta, dalam satu hari setiap orang rata-rata menghasilkan air limbah domestik sebanyak sekitar 200 liter. Angka ini menjadi semakin besar untuk masyarakat di negara-negara maju, karena semakin maju negaranya maka konsumsi air bersih dan jumlah air limbah yang dihasilkan juga semakin besar. Bila dihitung, beban pencemar organik BOD (Biochemical Oxygen Demand) yang dikandung air limbah yang dihasilkan satu orang dalam satu hari adalah sebesar 43,5 gram. Sumbangan terbesar beban pencemar ini adalah dari kegiatan di dapur dan toilet, yakni masing-masing 13 dan 16,8 g/orang/hari (Dinas Pekerjaan Umum Provinsi DKI Jakarta, 1990).

Untuk mengurangi dampak pencemaran oleh air limbah, pemerintah telah melakukan beberapa upaya, seperti menetapkan baku mutu air limbah yang boleh dibuang, membuat program kali bersih (prokasih), memberi teguran bahkan sangsi hukum kepada pemilik usaha yang terbukti mencemari lingkungan karena tidak mengolah air limbah sebagaimana mestinya. Khusus untuk mengurangi tingkat pencemaran oleh air limbah domestik di wilayah ibu kota, Pemerintah DKI Jakarta telah mengeluarkan Peraturan Gubernur Provinsi DKI Jakarta nomor 122 tahun 2005, tentang pengelolaan air limbah domestik dan baku mutu air limbah domestik, yang menjadi acuan untuk membuang air limbah domestik ke badan perairan di wilayah DKI Jakarta (Gubernur DKI Jakarta, 2005).

Pusat Perbelanjaan Pasaraya Blok M (untuk selanjutnya disingkat Pasaraya Blok M) terletak Jl. Iskandasyah II, No. 2 Blok M, Jakarta Selatan, merupakan salah satu pusat perbelanjaan yang sangat dikenal dan banyak dikunjungi. Disamping lokasinya yang strategis karena berada di tengah kota, juga mudah dijangkau dengan sarana transportasi umum karena terletak bersebelahan dengan Terminal Bis Blok M. Seperti telah disinggung di atas, pusat-pusat perbelanjaan seperti Pasaraya Blok $M$ ini adalah salah satu tempat yang banyak menggunakan air bersih sekaligus banyak menghasilkan air limbah domestik.

Untuk mengolah air limbah yang dihasilkannya, dari awal berdiri Gedung Pasaraya Blok $M$ sudah memiliki Instalasi Pengolahan Air Limbah (IPAL). Saat itu, sistem IPAL yang digunakan adalah proses Lumpur Aktif atau "Activated Sludge". Seiring berjalannya waktu dan bertambahnya debit air limbah, IPAL yang ada sudah tidak mampu mengolah air limbah yang masuk. Ini ditandai dengan masih tingginya konsentrasi beberapa parameter dalam air olahan IPAL, seperti konsentrasi senyawa Amonia $\left(\mathrm{NH}_{3}-\mathrm{N}\right)$ dan konsentrasi COD jauh di atas baku mutu yang ditetapkan.

Berkenaan dengan kondisi di atas, maka pada tahun 2014 untuk meningkatkan kinerja IPAL, manajemen Pasaraya Blok M melakukan renovasi, modifikasi dan optimalisasi terhadap IPAL yang ada. Renovasi dan modifikasi yang dilakukan antara lain merubah fungsi beberapa bak yang ada menjadi biofilter aerob agar efisiensi pengolahan lebih tinggi, menambah "fine bubble diffuser" pada bak aerasi agar persentuhan udara dengan air limbah lebih sempurna dan modifikasi sistem pengendapan mikroba pada bak pengendap agar mikroba dapat mengendap dengan baik sehingga endapan mikroba mudah dikembalikan ke dalam bak aerasi (Setiyono, dkk., 2012; lkbal, dkk., 2013).

\subsection{Tujuan}

Tujuan dari penelitian ini adalah untuk melihat dan mengetahui kinerja IPAL domestik Pasaraya Blok $M$ setelah dilakukan renovasi, modifikasi dan optimalisasi terhadap IPAL yang lama.

\section{PEMILIHAN TEKNOLOGI PENGOLAHAN AIR LIMBAH}

Tujuan pengolahan limbah adalah untuk menetralisir, menguraikan atau mengambil polutan-polutan yang ada di dalam limbah. Proses ini dilakukan secara terkontrol, sehingga dampak negatifnya terhadap lingkungan dapat dihindari. Lazimnya pengolahan air limbah yang digunakan adalah proses fisika, kimia-fisika dan proses biologi (Grady, C.P.L , dkk., 1980).

Proses fisika atau kimia-fisika umumnya 
dipakai untuk mengolah limbah-limbah anorganik seperti air limbah industri pertambangan, pelapisan atau pemurnian logam. Proses ini lebih banyak memanfaatkan perbedaan sifat-sifat fisik yang dimiliki oleh polutan dalam air limbah, seperti perbedaan berat jenis dengan proses pengendapan, perbedaan ukuran partikel dengan proses penyaringan dan perbedaan titik didih melalui proses penguapan. Beberapa contoh alat yang digunakan pada proses fisika dalam pengolahan limbah adalah tangki pengendap atau tangki sedimentasi, unit filtrasi seperti belt atau filter press dan wadah penguap seperti lagoon terbuka. Pemakaian bahan-bahan kimia pada pengolahan kimia-fisika, seperti penambahan senyawa koagulan dan senyawa flokulan dimaksudkan untuk membantu mengikat partikelpartikel halus yang tersuspensi dalam air limbah agar ukurannya menjadi besar dan berat sehingga mudah disaring atau diendapkan.

Pengolahan secara biologi lebih tepat digunakan untuk mengolah limbah-limbah organik. Pada pengolahan biologi, polutan-polutan organik dalam air limbah akan diuraikan secara biokimia oleh mikroba (mikroorganisme) menjadi senyawa sederhana yang sudah stabil. Cara ini relatif lebih murah bila dibandingkan dengan pengolahan secara kimia-fisika, karena tidak memerlukan bahan-bahan kimia tambahan. Di samping itu, proses ini sangat bersahabat dengan lingkungan, karena produk akhirnya hasil penguraian polutan merupakan senyawa-senyawa kimia yang sudah stabil (Rittman, B. E. dkk., 2001).

Proses biologi dikelompokkan atas biologi anaerobik dan aerobik. Proses biologi anaerobik atau lebih populer disebut proses fermentasi metan banyak digunakan untuk mengolah limbah organik berkonsentrasi tinggi, seperti limbah industri alkohol, gula, tapioka dan kelapa sawit (Ikbal, dkk, 1994; Kida,K., dkk, 1995). Mikroba yang bekerja disini adalah jenis anaerob, yaitu mikroba yang tidak membutuhkan udara dalam aktivitasnya, bahkan apabila lingkungannya terkontaminasi oleh udara mengakibatkan mikroba ini mati (Mc Carty, P.L., 1982). Pada proses biologi anaerobik, seperti dijelaskan pada Gambar 1, material organik yang ada dalam air limb ah akan didegradasi menjadi produk akhir berupa gas metana $\left(\mathrm{CH}_{4}\right)$ melalui proses hidrolisa, pembentukan asam-asam organik dan terakhir proses gasifikasi metana (Nagai, S. dkk., 1989).

Penambahan beberapa senyawa mineral seperti $\mathrm{Co}+3$ dan $\mathrm{Ni}+3$ dalam jumlah mikro kedalam air limbah, disamping dapat mempercepat proses penguraian polutan organik (memperpendek waktu tinggal) juga akan meningkatkan jumlah air limbah yang mampu diolah dalam satuan waktu tertentu
(Kida,K. dkk, 1991; 2001).

Sebaliknya, biologi aerobik dipakai untuk mengolah limbah organik berkonsentrasi rendah seperti limbah cair domestik, limbah industri makanan/minuman. Mikroba yang berfungsi di sini adalah mikroba aerob yang memerlukan oksigen atau udara di dalam aktifitasnya. Pada pengolahan air limbah, lazimnya proses anaerob ditempatkan di awal kemudian diikuti oleh proses aerob. Mekanisme penguraian pulotan oleh mikroba aerob adalah seperti berikut. Didalam proses ini, polutan organic akan diuraikan menjadi molekul air $\left(\mathrm{H}_{2} \mathrm{O}\right)$, karbondioksida $\left(\mathrm{CO}_{2}\right)$ dan senyawa Nitrat (Grady, C.P.L. dkk., 1980).

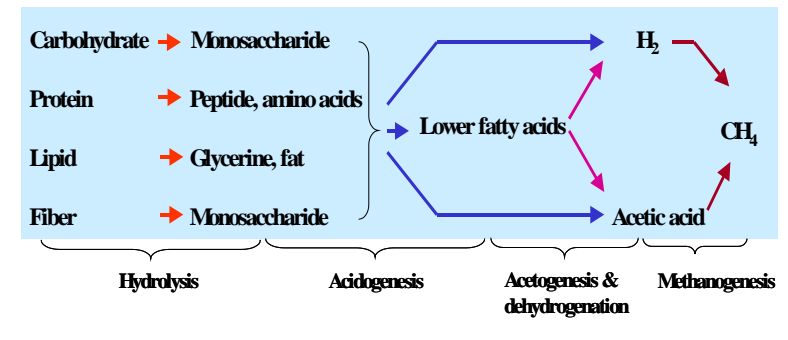

Gambar 1 : Mekanisme Penguraian Polutan Organik Secara Anaerob.

Reaksi Penguraian Organik pada proses biologi aerob:

$$
\underset{\text { Peterotropik }}{\stackrel{\text { Oksigen (O2) }}{\longrightarrow}} \mathrm{CO}_{2}+\mathrm{H}_{2} \mathrm{O}+\mathrm{NH}_{4}+\text { Biomasa }
$$

Reaksi Nitrifikasi :

$$
\begin{aligned}
& \mathrm{NH}_{4}^{+}+1,5 \mathrm{O}_{2} \longrightarrow \mathrm{NO}_{2}^{-}+2 \mathrm{H}^{+}+\mathrm{H}_{2} \mathrm{O} \\
& \mathrm{NO}_{2}^{-}+0,5 \mathrm{O}_{2} \longrightarrow \mathrm{NO}_{3}^{-}
\end{aligned}
$$

Seperti diketahui, kandungan utama polutan dalam air limbah domestik adalah bahan organik berkonsentrasi rendah. Berdasarkan karakteristik air limbah domestik ini, maka teknologi pengolahan air limbah yang dipilih adalah proses biologis aerob.

Kendala utama dalam pengolahan biologi adalah lambatnya proses penguraian bahan-bahan pencemar organik oleh mikroba. Untuk mengatasi kendala ini telah dilakukan berbagai usaha, diantaranya menaikkan atau mempertinggi konsentrasi mikroba dalam bioreaktor. Tingginya konsentrasi mikroba ini akan mempercepat proses degradasi polutan. Dengan tujuan meningkatkan konsentrasi mikroba di dalam bioreaktor, maka ke dalam bioreaktor dimasukkan bahan isian yang disebut media "biofilter" yang terbuat dari bahan plastik dan berbentuk "sarang tawon". Media ini berfungsi sebagai tempat melekat, tempat tumbuh dan sekaligus berkembang biak mikroba (Said, N.I., 
1995). Gambar 2 adalah contoh media biofilter yang banyak digunakan, termasuk pada IPAL Pasaraya Blok $\mathrm{M}$ setelah dimodifikasi.
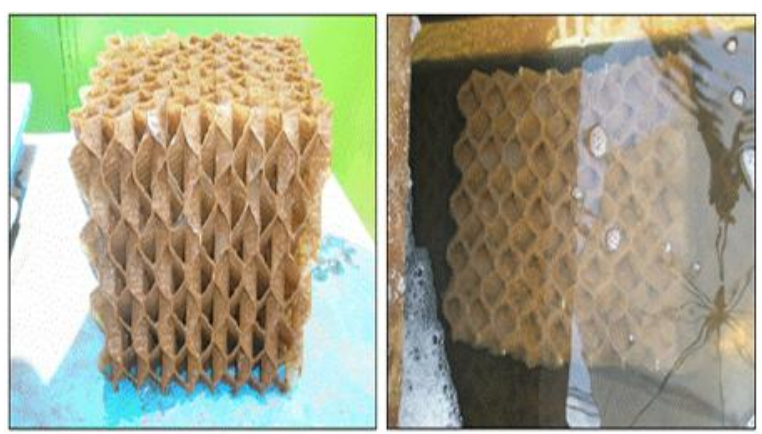

Gambar 2 : Media Biofilter (Kiri: Sebelum digunakan Kanan: Posisi Saat Digunakan dalam IPAL).

Dibawah ini disajikan beberapa keunggulan dari teknologi biofilter dalam pengolahan air limbah, yaitu:

\section{a. Biaya operasional murah}

Pada proses pengolahan secara biologis, termasuk biofilter tidak diperlukan biaya untuk pengadaan bahan-bahan kimia sebagaimana halnya pada proses kimia-fisika yang memerlukan bahan kimia koagulan dan flokulan, sehingga biaya operional murah.

\section{b. Pengoperasiannya mudah}

Di dalam proses pengolahan air limbah dengan sistem biofilter, mikroba yang keluar dari bioreaktor dan mengalir masuk bak pengendap sangat sedikit, sehingga tidak terjadi masalah "bulking" seperti halnya pada proses lumpur aktif konvensional (activated sludge process). Terjadinya bulking ditandai oleh sulitnya mikroba mengendap atau mikroba mengapung. Dalam pengolahan air limbah, hal ini sangat dihindarkan, karena apungan lumpur sangat mengganggu bahkan ikut keluar bersama air olahan. Pada proses biofilter hal ini dapat dihindarkan. Oleh karena itu pengelolaaanya sangat mudah.

\section{c. Lumpur yang dihasilkan sedikit}

Dibandingkan dengan proses lumpur aktif konvensional, lumpur yang dihasilkan pada proses biofilter relatif lebih kecil. Di dalam proses lumpur aktif antara 30 - $60 \%$ dari BOD yang dihilangkan (removal BOD) diubah menjadi lumpur aktif (biomasa) sedangkan pada proses biofilter hanya sekitar 10-30 \%. Hal ini disebabkan karena pada proses biofilter rantai makanan lebih panjang dan melibatkan aktifitas mikroorganisme dengan orde yang lebih tinggi dibandingkan proses konvensional seperti lumpur aktif.

\section{d. Mampu mengolah air limbah pada berbagai berkonsentrasi}

Di dalam proses pengolahan air limbah dengan sistem biofilter mikroorganisme atau mikroba melekat pada permukaan medium penyangga. Lapisan bagian dalam biofilm kondisinya anareb maka akan didominasi oleh mikroba bersifat anaerob yang mampu menguraikan polutan berkonsentrasi tinggi. Sedangkan lapisan bagian luar biofilm yang bersentuhan dengan udara akan didominasi oleh mikroba aerob yang tepat untuk pendegradasi polutan berkonsentrasi rendah. Oleh karena itu proses biofilter tersebut cocok digunakan untuk mengolah air limbah dengan konsentrasi tinggi maupun konsentrasi rendah.

\section{e. Tahan terhadap fluktuasi jumlah air limbah}

Di dalam proses biofilter, mikroba akan melekat pada seluruh permukaan media yang sangat luas. Dengan demikian konsentrasi biomassa mikroorganisme per satuan volume media menjadi sangat besar. Konsentrasi mikroba yang tinggi ini menyebabkan proses biofilter relatif tahan terhadap fluktuasi beban yang masuk.

\section{f. Tahan terhadap fluktuasi suhu}

Jika suhu air limbah turun maka lazimnya aktifitas mikroorganisme juga berkurang. Tetapi karena di dalam proses biofilter substrat maupun enzim yang dikeluarkan mikroba dapat terdifusi sampai ke bagian dalam lapisan biofilm dimana lapisan biofilm ini sangat tebal, maka pengaruh penurunan suhu tidak begitu besar terhadap proses biofilter. Fluktuasi suhu terutama terjadi di negaranegara yang memiliki musim dingin dan musim panas, seperti di Jepang.

\section{g. Lahan yang diperlukan lebih sedikit}

Karena konsentrasi mikroba dalam bioreaktor tinggi, maka waktu yang diperlukan untuk mengolah polutan-polutan dalam air limbah menjadi lebih singkat. Singkatnya waktu pengolahan ini, maka lahan yang diperlukan untuk membangun IPAL juga lebih sedikit dibanding sistem konvensional. lebih 


\section{IPAL PASARAYA BLOK M}

\subsection{Penggunaan Air Bersih dan Timbulan Air Limbah}

Sumber utama air bersih untuk kegiatan Pasaraya Blok $M$ adalah air dari PAM
(PerusahaanAir Minum) dan sebagai cadangan saat air PAM tidak mencukupi, digunakan air tanah yang sudah memiliki SIPA. Dari rekening tagihan air bersih bulanan, diketahui jumlah kebutuhan air bersih setiap hari berkisar antara $350-450 \mathrm{~m}^{3}$. Gambar 3 adalah neraca pemakaian air Pasaraya Blok $\mathrm{M}$.

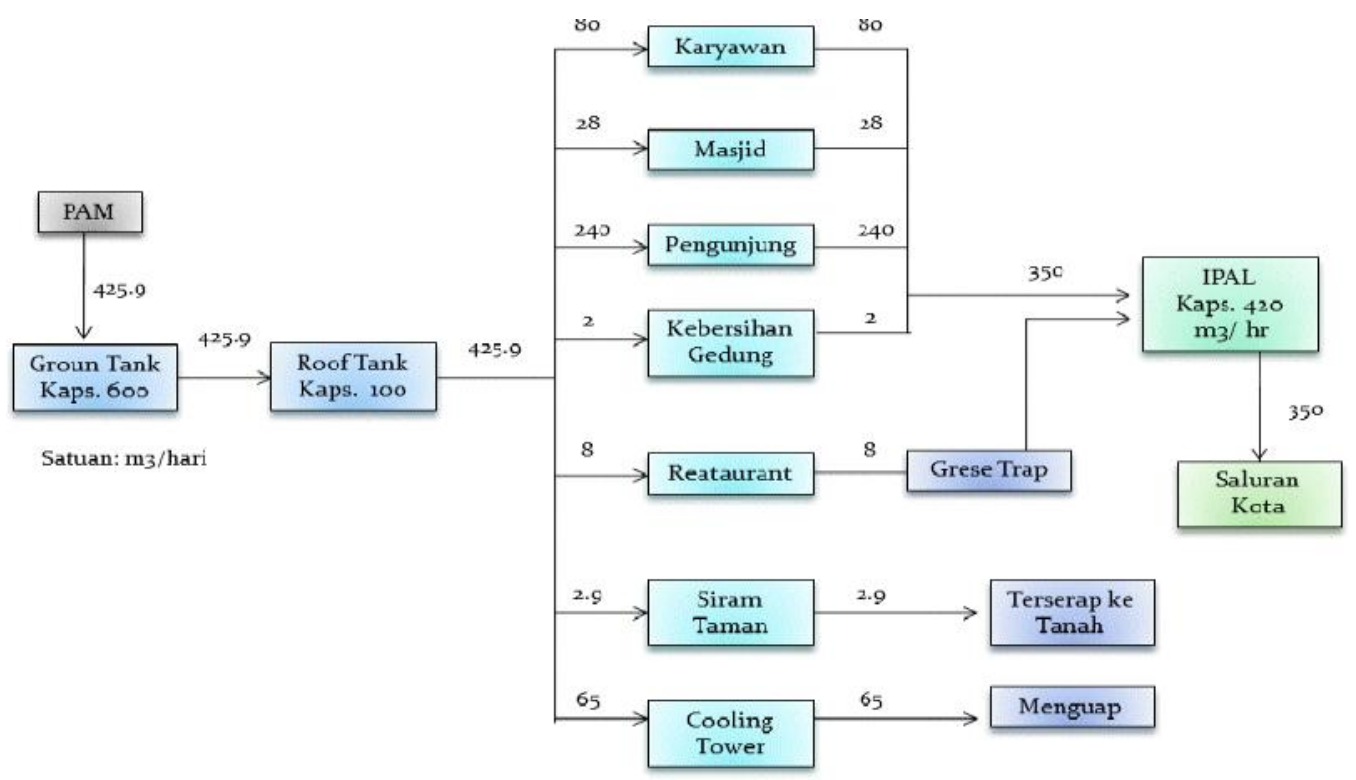

Gambar 3 : Neraca Air Pasaraya Blok M.

Jenis dan besarnya penggunaan air bersih pada masing-masing kegiatan adalah seperti terlihat pada Gambar 3, yaitu untuk kebutuhan pengunjung, untuk karyawan, unit cooling tower untuk pengatur suhu ruangan, untuk wudhu di masjid, kebersihan gedung dan untuk siram taman. Penggunaan air bersih terbesar di samping untuk pengunjung adalah untuk pendingin pada cooling tower. Semua air bersih yang digunakan ini, praktis akan terbuang sebagai air limbah domestik, kecuali air untuk cooling tower yaitu akan menguap dan air untuk siram taman yang akan meresap ke dalam tanah. Pada kegiatan Pasaraya Blok $M$, semua air limbah telah dialirkan masuk ke dalam IPAL untuk diolah sampai layak dibuang, sehingga dapat dipastikan tidak akan mencemari lingkungan. Khusus untuk air limbah dari kegiatan restoran, sebelum masuk IPAL dilewatkan dulu pada unit grease trap untuk memisahkan polutan minyak dan lemak yang ada dalam air limbah dengan proses pengapungan (flotasi).

\subsection{Instalasi Pengolahan Air Limbah (PAL)}

Pengolahan air limbah (IPAL) Pasaraya Blok $M$ terletak di lantai basement gedung. Untuk menjaga agar udara segar tetap tersedia di ruangan IPAL, maka ruangan IPAL dibuat terkoneksi langsung dengan area luar melalui pipa-pipa penyuplai udara. Gambar 4 adalah diagram alir proses pengolahan air limbah Pasaraya Blok M. Disini Sistem pengolahan air limbah disini menggunakan teknologi kombinasi antara proses lumpur aktif dengan proses biofilter aerob. Proses Lumpur aktif ditempatkan di depan, kemudian diikuti biofilter aerob di belakangnya.

Di samping itu, pada tahap awal juga ada proses fisika yaitu proses pengapungan (flotasi) untuk memisahkan minyak dan lemak dan proses penyaringan untuk mengambil benda-benda kasar yang ikut bersama air limbah.

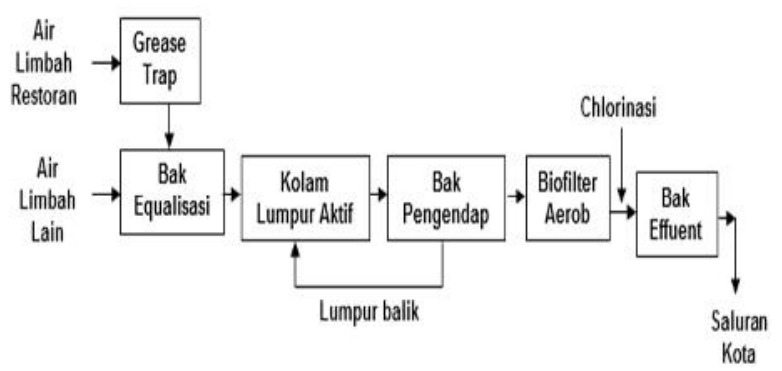

Gambar 4 : Diagram Alir Pengolahan Air Limbah Pasaraya Blok M. 
Pada tahap akhir sebelum air olahan dibuang keluar, juga dilakukan proses kimia yaitu proses chlorinasi untuk membunuh mikroba-mikroba yang bersifat patogen yang terdapat dalam air limbah domestik.

Gambar 5 adalah skema rangkaian IPAL Pasaraya Blok M. Alat utama IPAL adalah bak equalisasi, bak aerasi atau reaktor lumpur aktif, bak pengendap mikroba, bak atau reaktor biofilter aerob dan bak effluent. Alur proses pengolahan air limbah dari awal sampai akhir adalah sebagai berikut:

Air limbah dari restoran, setelah melewati unit grease trap untuk memisahkan minyak dan lemak yang ada dalam air limbah, mengalir masuk bak equalisasi. Air limbah dari sumber lain seperti dari toilet kamar mandi, kebersihan gedung dan air bekas wudhu, langsung masuk bak equalisasi yang dilengkapi dengan unit saringan.

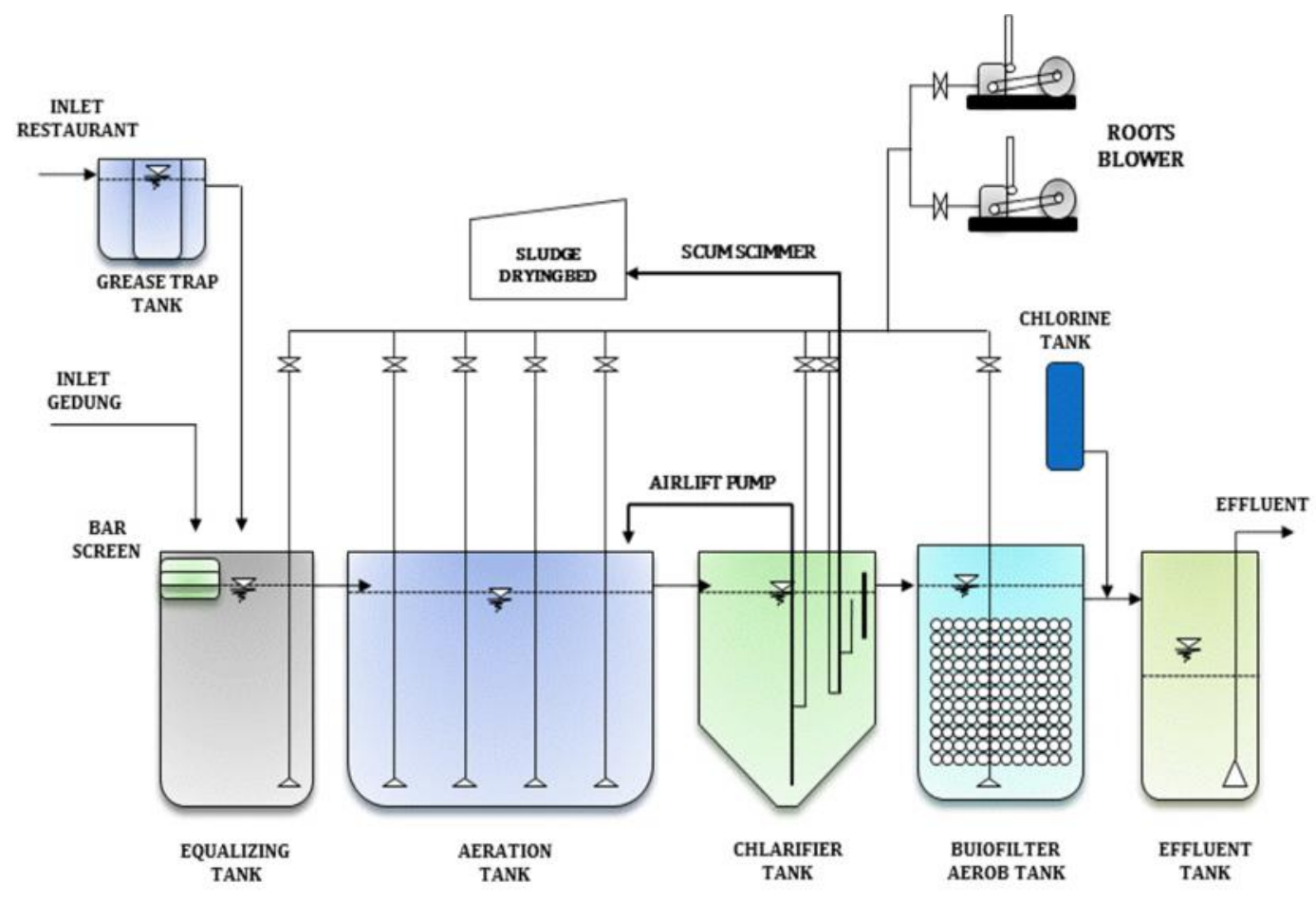

Gambar 5 : Skema Rangkaian IPAL Pasaraya Blok M.

Dari bak equalisasi, air limbah mengalir masuk bak lumpur aktif, terus menuju bak pengendap mikroba, kemudian mengalir masuk reaktor biofilter aerob dan terakhir masuk bak effluent setelah melalui proses chlorinasi. Dari bak effluent, air olahan dipompa menuju saluran drainase.

Sementara itu, endapan lumpur mikroba, dari dasar bak pengendap dikembalikan ke dalam bak lumpur aktif dengan bantuan sistem "air lift" memanfaatkan udara dari blower. Jika endapan lumpur terlalu banyak, sebagian akan dialirkan ke unit sludge drying bed untuk dikeringkan dan diangkut keluar. Ke dalam bak equalisasi, bak aerasi dan bak reaktor biofilter disuplai udara dari unit blower untuk membantu proses pengadukan dan proses penguraian polutan-polutan organik yang ada dalam air limbah.

Gambar 6 adalah foto IPAL Pasaraya Blok M. Di sebelah kanan adalah bak equalisasai dan bak aerasi. Sedangkan di sebelah kiri adalah bak pengendap mikroba, bak biofilter dan bak effluent. Tangki-tangki di ujung sebelah kiri adalah unit-unit filter untuk daur ulang air. Saat ini proses daur ulang air olahan IPAL masih belum dilaksanakan. Kedepan, nanti tangki-tangki ini akan difungsikan.

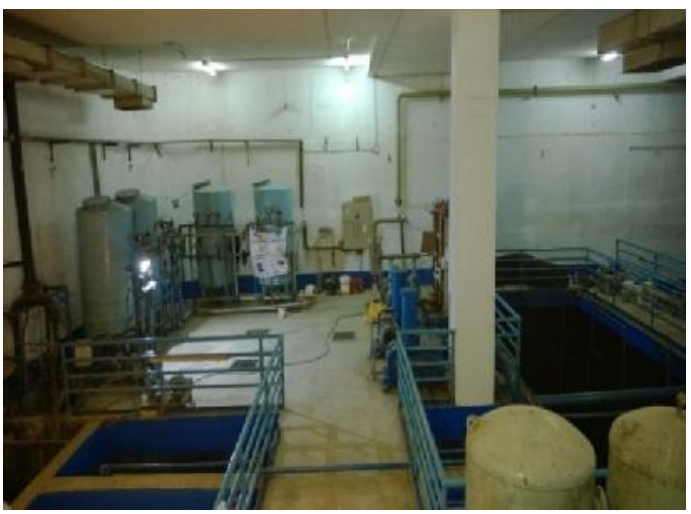

Gambar 6. Foto IPAL Pasaraya Blok M. 
Selanjutnya ini akan dijelaskan satu per satu unit-unit IPAL yang ada dan fungsi dari masingmasing unit tersebut.

\section{a. Saringan}

Saringan berupa keranjang terbuat dari kawat aluminium, berfungsi untuk menyaring kotoran kasar seperti sampah plastik, kertas dan pembalut wanita yang ikut mengalir bersama air limbah. Sampah harus dicegah jangan sampai terbawa masuk ke dalam IPAL. Sampah yang masuk IPAL akan menggangu proses seperti menyumbat perpipaan, mengganggu proses aerasi karena akan menutupi permukaan air, menyumbat pompa dan lainnya. Secara berkala, pagi dan sore, sampahsampah yang tertahan pada unit saringan, dipungut dan dibuang ke dalam bak sampah.

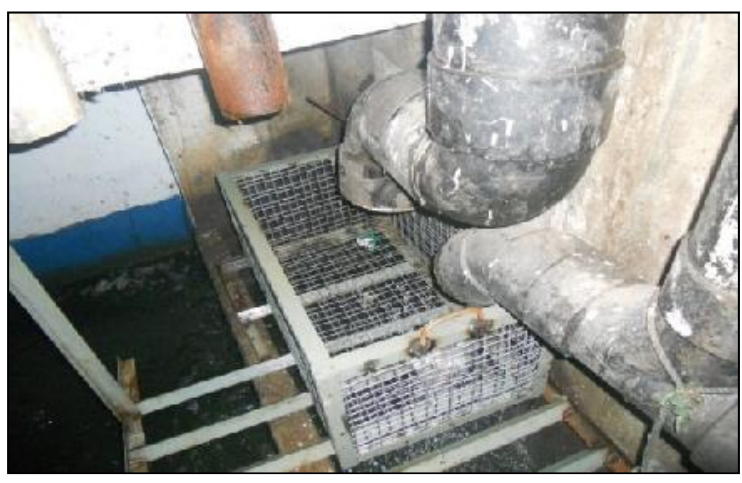

Gambar 7 : Unit Saringan IPAL Pasaraya Blok M.

\section{b. Bak Equalisasi}

Bak equlisasi berfungsi untuk penyeragaman air limbah yang masuk sebelum diolah pada bak aerasi. Air limbah berasal dari berbagai sumber dengan jenis dan konsentrasi polutan yang berbeda. Misalnya air limbah dari restoran banyak mengandung minyak dan lemak, dari toilet mengadung konsentrasi Ammonia tinggi.

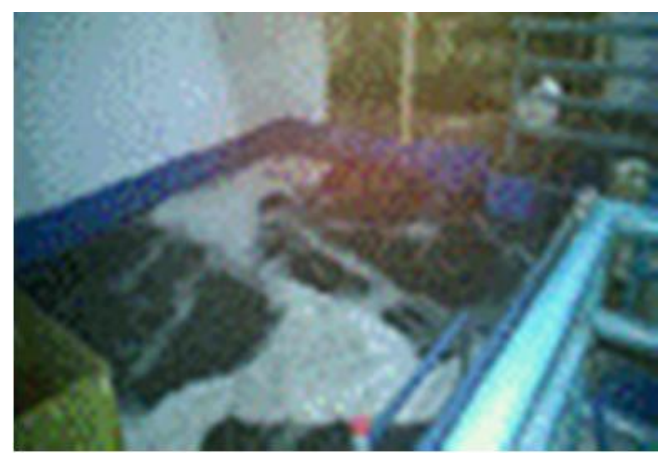

Gambar 8 : Bak Equalisasi IPAL Pasaraya Blok M.
Di dalam bak equalisasi, semua air limbah yang masuk, dicampur dan diaduk dengan bantuan udara supaya homogen. Kehomogenan air limbah ini dapat mencegah fluktuasi beban yang masuk IPAL, sehingga kinerja IPAL bisa selalu stabil dan dapat dipertahankan tetap tinggi. Dari bak equalisasi, air limbah mengalir masuk bak aerasi.

\section{c. Bak Aerasi atau Bak Lumpur Aktif}

Bak aerasi berfungsi sebagai tempat atau wadah pengolahan air limbah. Di sini, polutanpolutan organik yang ada dalam air limbah, seperti karbohidrat, minyak, lemak, protein dan senyawasenyawa sellulose akan diuraikan secara biokimia oleh mikroba menjadi senyawa stabil seperti molekul air $\left(\mathrm{H}_{2} \mathrm{O}\right)$, karbon dioksida $\left(\mathrm{CO}_{2}\right)$ dan Nitrat $\left(\mathrm{NO}_{3}\right)^{-}$. Bak aerasi disebut juga bak lumpur aktif, karena di dalam bak ini terjadi percampuran sempurna antara mikroba berbentuk butiranbutiran lumpur yang aktif dengan air limbah. Pada dasar bak aerasi dipasang diffuser udara "fine bubble" berbentuk piring atau mangkok, dengan tujuan supaya udara yang disuplai dari blower bisa merata ke seluruh area bak aerasi. Semakin banyak dan semakin lama persentuhan antara udara dengan air di dalam bak aerasi, maka proses penguraian polutan oleh mikroba juga akan semakin cepat dan sempurna. Jumlah suplai udara harus dihitung, harus mencukupi untuk kebutuhan oksidasi polutan-polutan organik dalam air limbah dan untuk bernafas mikroba. Banyak ditemui kegagalan dalam proses lumpur aktif, karena jumlah kebutuhan udara tidak diperhitungkan. Dari bak aerasi, air olahan mengalir masuk bak pengendap.

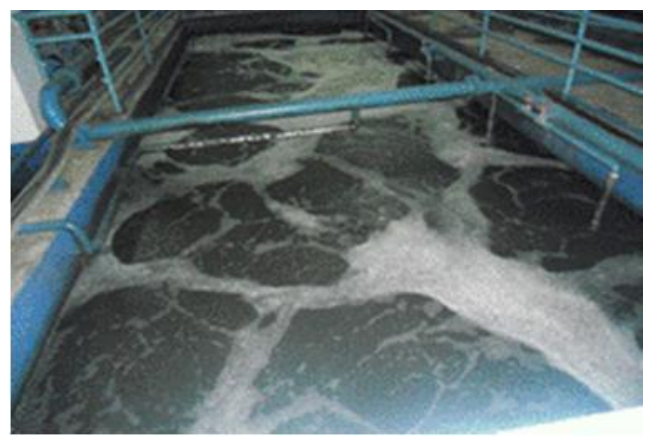

Gambar 9 : Bak Aerasi IPAL Pasaraya Blok M.

\section{d. Bak Pengendap Mikroba}

Bak pengendap mikroba berfungsi untuk memisahkan miroba yang ikut mengalir bersama air olahan dari bak aerasi masuk bak pengendap. Di sini mikroba akan mengendap secara gravitasi karena perbedaan adanya perbedaan berat jenis. 
Endapan mikroba kemudian dikembalikan ke dalam bak aerasi untuk menjaga agar konsentrasi mikroba di dalam bak aerasi tetap tinggi. Pengembalian lumpur mikroba ke dalam bak aerasi dilakukan dengan bantuan air lift. Jika sewaktu-waktu konsentrasi mikroba di dalam bak aerasi terlalu tinggi, maka sebagian endapan mikroba dari bak pengendap harus dibuang keluar melalui unit pengering lumpur atau sludge drying bed.

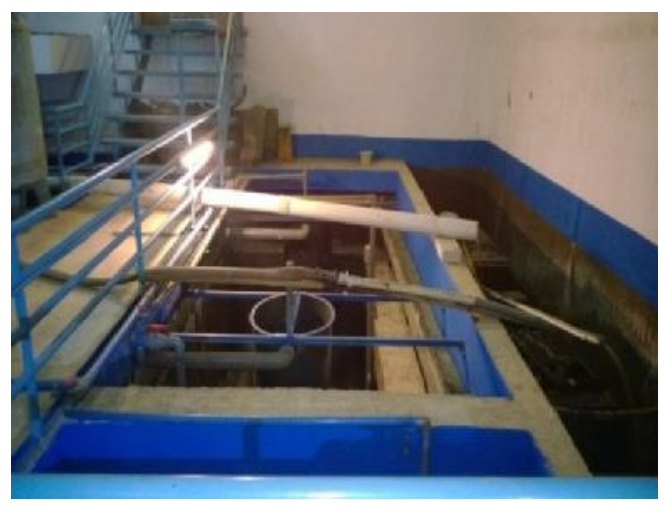

Gambar 10 : Bak Pengendap Mikroba IPAL Pasaraya Blok M.

\section{e. Bak Biofilter Aerob}

Bak biofilter aerob berfungsi sebagai tempat pengolahan lanjutan. Di sini, sisa-sisa polutan yang belum sempat terurai pada bak aerasi akan diolah lebih lanjut. Bak biofilter dilengkapi dengan media isian dari bahan plastik berbentuk "sarang tawon".

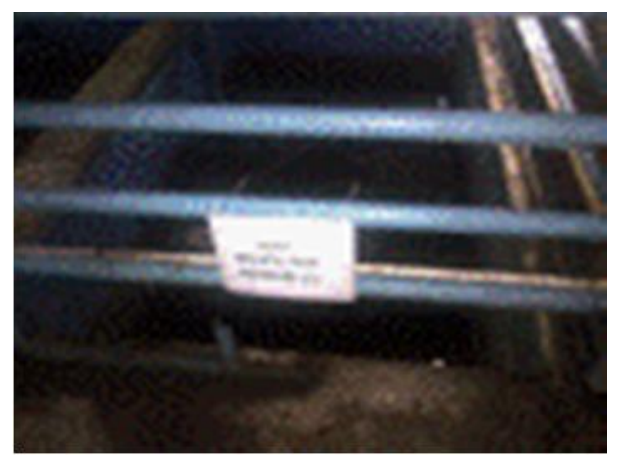

Gambar 11 : Bak Biofilter Aerob IPAL Pasaraya Blok M.

Media isian berfungsi sebagai tempat tumbuh dan berkembangbiak mikroba. Secara terperinci terkait proses biofilter, telah dijelaskan didepan. Untuk mensuplai udara dari blower, biofilter aerob juga dilengkapi dengan fine bubble diffuser yang ditempatkan di dasar bak. Air olahan, dari biofilter aerob selanjutnya mengalir masuk bak effluent.

\section{f. Bak Penampung Hasil (Effluent Tank)}

Bak penampung hasil berfungsi sebagai wadah penampung air olahan sebelum dibuang ke luar. Bak ini dilengkapi dengan unit chlorinasi untuk membunuh mikroba-mikroba patogen yang ikut mengalir bersama air limbah. Caranya, ke dalam bak effluent diteteskan larutan klorida atau kaporit. Bak effluent dilengkapi dengan pompa untuk mengalirkan air limbah keluar. Pada bagian outlet bak, dipasang "flow meter" untuk membaca jumlah atau "debit" air limbah yang keluar dari IPAL. Dari jumlah air limbah ini selanjutnya bisa dihitung beban atau "loading" IPAL. Bak ini juga dilengkapi dengan pipa untuk mengambil sampel air olahan IPAL, untuk keperluan analisa laboratorium untuk mengetahui kualitas air hasil olahan.
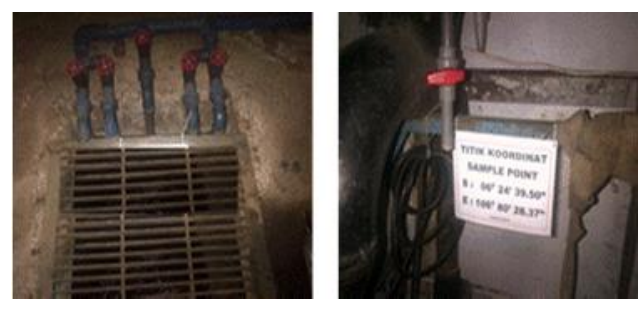

Gambar 12 : Bak Effluent (kiri) dan Titik Pengambilan Sampel (kanan).

\section{g. Blower Udara}

Blower udara berfungsi untuk menyuplai udara. Udara dibutuhkan antara lain untuk pegadukan supaya air dalam bak-bak homogen, untuk bernafas mikroba dan juga sebagai oksidator pada reaksi oksidasi penguraian molekul-molukel polutan dalam air limbah oleh mikroba. Karena IPAL harus beroperasi selama 24 jam, maka suplai udara dari blower juga harus 24 jam. Artinya blower harus hidup siang dan malam. IPAL Pasaraya Blok M memiliki 2 unit blower tipe "root blower". Kedua blower ini hidup bergantian, diatur menggunakan timer.

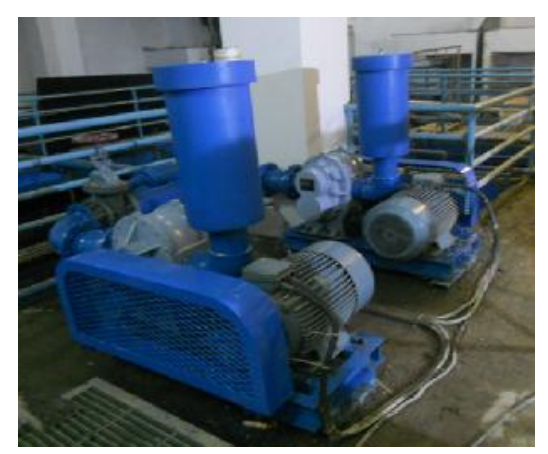

Gambar 13 : Blower Udara IPAL Pasaraya Blok M. 


\section{METODOLOGI}

Metododa yang digunakan untuk evaluasi kinerja IPAL adalah dengan melakukan analisa laboratorium secara berkala terhadap kualitas air olahan IPAL. Analisa dilakukan di laboratorium yang sudah diakreditasi dan diakui oleh pemerintah. Lokasi tempat pengambilan sampel air olahan dilakukan pada titik yang sama, yaitu pada titik outlet IPAL yang sudah ditandai dengan pemberian ordinat (Gambar 12, kanan).

Metoda analisa mengikuti metoda baku yaitu sesuai dengan Standar Nasional Indonesia (SNI) dan Spektrofotometri. Parameter yang diukur mengikuti parameter baku mutu air limbah domestik yang ditetapkan dalam Peraturan Gubernur Propinsi DKI Jakarta, Nomor 122 tahun 2005, yang merupakan rujukan dalam pengelolaan air limbah domestik di Propinsi DKI Jakarta. Jumlah parameter yang dinalisa ada 8 parameter, seperti berikut:

- Derajad keasaman (pH), diukur menggunakan metoda SNI 06-6989.11-2004.

- Kalium Permanganat $\left(\mathrm{KMnO}_{4}\right)$, diukur menggunakan metoda SNI 06-6989.22-2004.

- Zat padat tersuspensi (TSS atau Total Suspended Solid), diukur menggunakan metoda 18-7/IK/A (Spektrofotometri).

- Amoniak $\left(\mathrm{NH}_{3}-\mathrm{N}\right)$, diukur menggunakan metoda SNI 06-6989.30-2005.

- Minyak dan lemak, diukur menggunakan metoda SNI 6989.10-2022.

- Deterjen (MBAS), diukur menggunakan metoda SNI 06-6989.51-2005.

- COD (Chemical Oxygen Demand), diukur menggunakan metoda SNI 6989.2-2009.

- BOD5 (Biochemical Oxygen Demand), diukur menggunakan metoda SNI 6989.72-2009.

Tabel 1 : Baku Mutu Air Limbah Domestik*

\begin{tabular}{clcc}
\hline No. & Parameter & Satuan & Besaran \\
\hline 1. & $\mathrm{pH}$ & $(-)$ & $6-9$ \\
2. & $\mathrm{KMnO}_{4}$ & $(\mathrm{mg} / \mathrm{l})$ & 85 \\
3. & $\mathrm{TSS}$ & $(\mathrm{mg} / \mathrm{l})$ & 50 \\
4. & Amonia $\left(\mathrm{NH}_{3}-\mathrm{N}\right)$ & $(\mathrm{mg} / \mathrm{l})$ & 10 \\
5. & Minyak dan lemak & $(\mathrm{mg} / \mathrm{l})$ & 10 \\
6. & Deterjen (MBAS) & $(\mathrm{mg} / \mathrm{l})$ & 2 \\
7. & COD & $(\mathrm{mg} /)$ & 80 \\
8. & BOD & $(\mathrm{mg} /)$ & 50
\end{tabular}

*Per. Gub. Prop. DKI Jakarta, Nomor 122 tahun 2005
Pada Tabel 1 disajikan baku mutu air limbah domestik seperti tertera dalam Peraturan Gubernur Propinsi DKI Jakarta, Nomor 122 tahun 2005, yang menjadi acuan dalam pengelolaan air limbah. Baku mutu adalah nilai ambang tertinggi yang diizinkan untuk layak dibuang ke lingkungan, seperti ke badan penerima air.

Selanjutnya, cara yang digunakan untuk menghitung efisiensi pengurangan konsentrasi polutan setelah diolah adalah konsentrasi polutan dalam air limbah sebelum diolah (inlet) dikurangi konsentrasi polutan dalam air olahan (outlet), kemudian dibagi dengan konsentrasi polutan dalam air limbah sebelum diolah dan dikali $100 \%$.

\section{HASIL DAN PEMBAHASAN}

\subsection{Air limbah Pasaraya Blok M}

Konsentrasi polutan-polutan dalam air limbah yang dihasilkan kegiatan Gedung Pasaraya Blok M seperti pada Tabel 2.

Tabel 2 : Hasl Analisa Kualitas Air Limbah Pasaraya Blok $\mathrm{M}$.

\begin{tabular}{clcc}
\hline No & Parameter & Satuan & Besaran \\
\hline 1. & $\mathrm{pH}$ & $(-)$ & 7,3 \\
2. & $\mathrm{KMnO}_{4}$ & $(\mathrm{mg} / \mathrm{l})$ & 185,8 \\
3. & TSS & $(\mathrm{mg} / \mathrm{l})$ & 141 \\
4. & Amonia $\left(\mathrm{NH}_{3}-\mathrm{N}\right)$ & $(\mathrm{mg} / \mathrm{l})$ & 16,3 \\
5. & Minyak \& lemak & $(\mathrm{mg} / \mathrm{l})$ & 0,5 \\
6. & Deterjen (MBAS) & $(\mathrm{mg} / \mathrm{l})$ & 1,03 \\
7. & COD & $(\mathrm{mg} /)$ & 297 \\
8. & BOD & $(\mathrm{mg} /)$ & 103 \\
\hline
\end{tabular}

Seperti terlihat pada tabel di atas, konsentrasi semua polutan organik $\left(\mathrm{KMnO}_{4}, \mathrm{TSS}\right.$, COD, BOD) dan Amonia $\left(\mathrm{NH}_{3}-\mathrm{N}\right)$ dalam air limbah sangat tinggi, jauh di atas baku mutu yang ditetapkan. Polutan-polutan organik berasal dari sisa-sisa makanan dalam tinja dan juga dari restoran, sedangkan senyawa Amonia sebagian besar berasal dari air seni. Kandungan minyak dan lemak dalam air limbah cukup rendah. Ini menandakan bahwa proses pemisahan minyak dan lemak pada unit-unit grease trap sebelum masuk IPAL, berjalan dengan baik. Air limbah ini selanjutnya dialirkan masuk IPAL untuk diolah. Di dalam penelitian ini dilakukan pendekatan bahwa konsentrasi polutan dalam air limbah yang masuk IPAL (inlet) dianggap konstan, yaitu seperti yang tertera di dalam Tabel 2. Tahap selanjutnya, yang dianalisa hanya air olahan IPAL saja. 


\subsection{Air Olahan IPAL}

Pengambilan sampel dan analisa dilakukan setiap bulan secara terus menerus selama kurun waktu 1 tahun, dimulai dari bulan Januari sampai bulan Desember tahun 2016. Parameter yang diamati dan dibahas pada tulisan ini hanya parameter yang konsentrasinya tinggi, melebihi baku mutu (Tabel 2), yaitu $\mathrm{KMnO}_{4}$, TSS, Amonia $\left(\mathrm{NH}_{3}-\mathrm{N}\right), \mathrm{COD}$ dan BOD. Disini parameter $\mathrm{pH}$ juga dibahas, karena $\mathrm{pH}$ merupakan parameter kunci dan menentukan kesuksesan di dalam proses pengolahan air limbah. Parameter minyak dan lemak serta Deterjen (MBAS) tidak dibahas karena konsentrasinya di dalam air limbah sudah rendah, di bawah baku mutu. Setelah diolah, konsentrasi kedua parameter ini jauh lebih rendah lagi.

\section{a. pH (derajad keasaman)}

Seperti dijelaskan di atas, pH adalah salah satu parameter penting dalam pengolahan air limbah, khususnya sistem biologi. Secara umum, mikroba pengurai polutan dalam air limbah akan tumbuh dan beraktifitas dengan baik pada kondisi $\mathrm{pH}$ netral. Pada beberapa kasus, $\mathrm{pH}$ di dalam bak aerasi cenderung turun atau rendah. Hal ini bisa terjadi disebabkan karena kurangnya suplai udara atau akumulasi asam-asam organik sebagai produk antara dalam bak aerasi. Hal ini tidak diinginkan dan harus dihindari, misalnya menambah suplai udara.

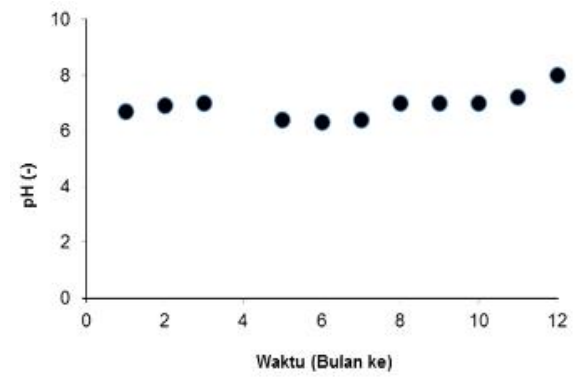

Gambar 14 : Perubahan pH Air Olahan IPAL Pasaraya Blok M .

Pada IPAL Pasaraya Blok $\mathrm{M}$, selama 1 tahun pengoperasian IPAL, seperti terlihat pada Gambar 14, nilai $\mathrm{pH}$ sangat baik dan relatif stabil, berkisar antara 6,5 sampai 8,0 . Berada dalam rentang batas baku mutu yangditetapkan antara 6,0 smpai 9,0.

\section{b. Kalium Permanganat $\left(\mathrm{KMnO}_{4}\right)$}

Di antara beberapa parameter organik, mengukur kosentrasi Kalium Permanganat $\left(\mathrm{KMnO}_{4}\right)$ adalah cara paling cepat dan mudah untuk melihat jumlah kandungan polutan organik yang ada dalam air limbah. Cara ini banyak dilakukan karena di samping mudah dan cepat juga paling murah. Gambar 15 adalah grafik hubungan antara waktu opererasi IPAL dengan konsentrasi dan efisiensi pengurangan parameter $\mathrm{KMnO}_{4}$. Ordinat di sebelah kiri adalah konsentrasi $\mathrm{KMnO}_{4}$ (bulat tertutup, air limbah sebelum diolah; bulat terbuka setelah diolah). Ordinat di sebelah kanan adalah efisiensi pengurangan $\mathrm{KMnO}_{4}$. Di dalam Tabel 2 terlihat, konsentrasi $\mathrm{KMnO}_{4}$ dalam air limbah cukup tinggi, mencapai 185,5 mg/l. Selama 12 bulan IPAL beroperasi, konsentrasi $\mathrm{KMnO}_{4}$ dalam air olahan selalu di bawah $20 \mathrm{mg} / \mathrm{l}$. Efisiensi pengurangan $\mathrm{KMnO}_{4}$ juga sangat tinggi di atas $90 \%$, bahkan mencapai 99 \% pada bulan November 2016. Baku mutu konsentrasi $\mathrm{KMnO}_{4}$ dalam Tabel 1 adalah 85 $\mathrm{mg} / \mathrm{l}$.

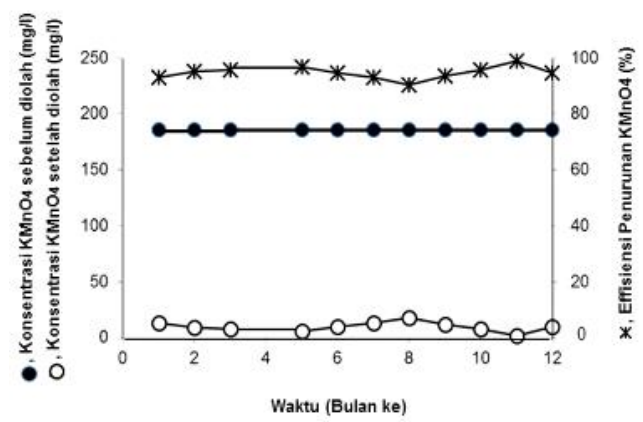

Gambar 15 : Konsentrasi $\mathrm{KMnO}_{4}$ Sebelum dan Setelah Diolah serta Efisensi Penurunan $\mathrm{KMnO}_{4}$.

\section{c. Total Suspended Solid (TSS)}

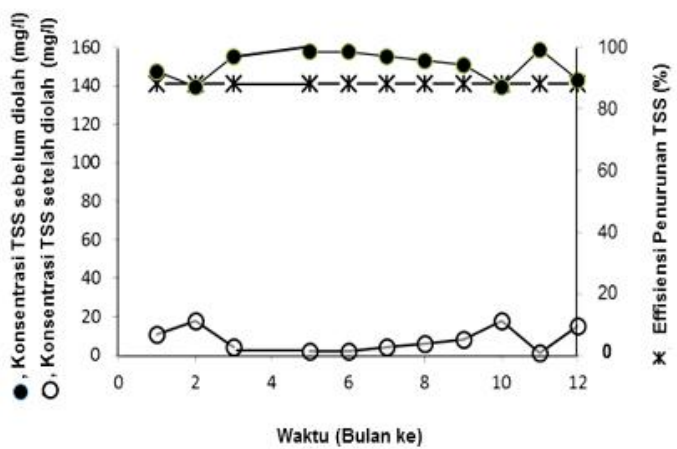

Gambar 16 : Konsentrasi TSS Sebelum dan Setelah Diolah serta Efisensi Penurunan TSS.

Total Suspended Solid (TSS) menunjukkan kandungan partikel padat dalam air limbah. Pada air limbah domestik, TSS merupakan senyawa organik berupa padatan. Di dalam pengolahan air limbah, khususnya proses biologi, konsentrasi TSS yang tinggi sangat dihindarkan karena memerlukan waktu lebih lama untuk menguraikannya. Proses aerasi yang baik dalam bak aerasi sangat membantu proses degradasi partikel padat ini. 
Seperti terlihat pada Tabel 2, konsentrasi TSS dalam air limbah Pasaraya Blok M sebesar 141 $\mathrm{mg} / \mathrm{l}$. Seperti terlihat pada Gambar 16, selama tahun 2016, konsentrasi TSS pada air olahan sangat rendah, selalu di bawah $20 \mathrm{mg} / \mathrm{l}$. Efisiensi penguraian TSS juga sangat tinggi diatas 90\%, bahkan pada bulan November 2016 mencapai 99\%. Baku mutu konsentrasi TSS adalah 50 mg/l.

\section{d. Amonia $\left(\mathrm{NH}_{3}-\mathrm{N}\right)$}

Senyawa Amonia dalam air limbah berasal dari urine dan sisa-sisa makan yang mengandung protein. Senyawa Amonia, khususnya H tinggi, konsentrasi Amonia bebas akan meningkatkan Amonia bebas bersifat toksid atau racun. Pada konsentrasi yang pekat, dapat mengganggu aktifitas mikroba. Pada unit pengolahan air limbah yang mengandung kadar Amonia tinggi, diperlukan $\mathrm{pH}$ kontrol dan larutan asam untuk menurunkan $\mathrm{pH}$. Amonia juga bisa timbul dari pembusukan mikroba terutama pada bak pengendap atau dari apungan lumpur yang terlalu lama dibiarkan pada permukaan bak-bak IPAL. Untuk mencegahnya, lumpur pada bak pengendap harus sering diambil dan IPAL harus dibersihan dari lumpur yang mengapung. Pada air limbah Pasaraya Blok M, konsentrasi Amonia 16,3 mg/l.

Pada pengolahan biologi aerob, senyawa Amonia akan dioksidasi secara biokimia oleh mikroba menjadi senyawa Nitrit $\left(\mathrm{NO}_{2}\right)_{-}$, kemudian dioksidasi lanjut menjadi Nitrat ( $\left.\mathrm{NO}_{3}\right)^{-}$. Pada Gambar 17 terlihat, konsentrasi Amonia pada air olahan selama setahun IPAL beroperasi, sangat berfluktuasi, antara 1 sampai 9,3 mg/l. Demikian juga efisiensi penurunan Amonia juga bervariasi antara 45 sampai 94\%. Efisiensi terendah pada bulan Januari dan bulan Juni 2017, yakni sebesar 45\%. Tertinggi pada bulan Februari, bulan Oktober dan bulan November yaitu 94\%. Baku mutu konsentrasi Amonia untuk air limbah domestik adalah $10 \mathrm{mg} / \mathrm{l}$ (Tabel 1).

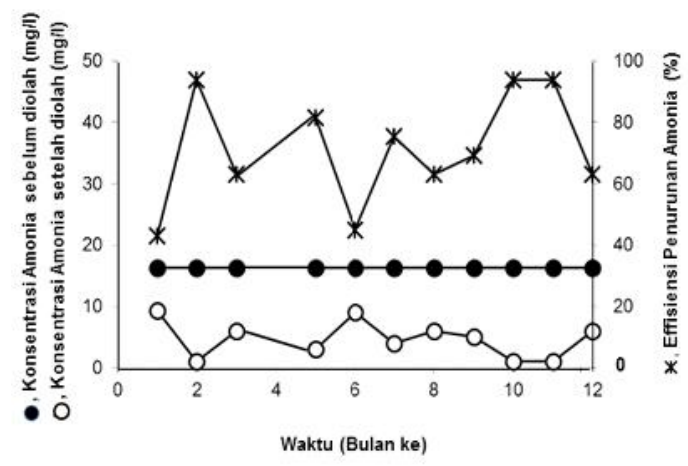

Gambar 17 : Konsentrasi Amonia Sebelum dan Setelah Diolah serta Efisensi Penurunan Amonia.

\section{e. Chemical Oxygen Demand (COD)}

Chemical Oxygen Demand atau disingkat dengan COD merupakan parameter sangat penting dalam menentukan tingkat pencemaran. COD adalah kebutuhan oksigen untuk mengoksidasi polutan-polutan organik melalui reaksi kimia menjadi senyawa akhir seperti $\mathrm{H}_{2} \mathrm{O}, \mathrm{CO}_{2}, \mathrm{NO}_{3}{ }^{-}$dan lainnya. Jadi COD bukan polutan pencemar, tetapi ukuran tingkat pencemaran. Semakin tinggi nilai COD, maka kebutuhan oksigen juga semakin besar dan secara otomatis kandungan polutan dalam air limbah tersebut juga makin tinggi. Bila dilihat, nilai COD pada air limbah Pasaraya Blok M adalah 297 $\mathrm{mg} / \mathrm{l}$ (Tabel 2), artinya untuk menguraikan senyawa-senyawa polutan dalam 1 liter air limbah, dibutuhkan oksigen sebanyak $297 \mathrm{mg}$. Selama 1 tahun IPAL beroperasi, seperti terlihat pada Gambar 18, nilai COD dalam air olahan dapat diturunkan mencapai di bawah $10 \mathrm{mg} / \mathrm{l}$. Selanjutnya, efisiensi pengurangan COD juga sangat tinggi, selalu di atas 90\%. Penurungan tertinggi adalah $98 \%$ pada bulan November 2016. Baku mutu untuk nilai COD air limbah domestik adalah 80 $\mathrm{mg} / \mathrm{l}$.

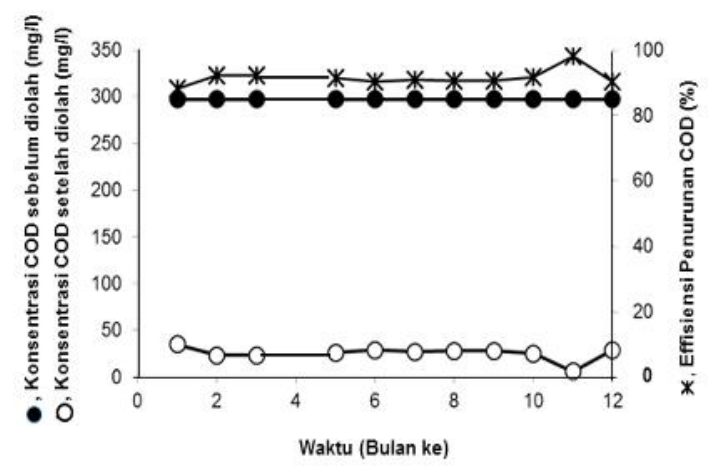

Gambar 18 : Konsentrasi COD Sebelum dan Setelah Diolah serta Efisensi Penurunan COD.

\section{f. Biochemical Oxygen Demand (BOD5)}

BOD juga parameter penting dalam menilai tingkat pencemaran. BOD adalah kebutuhan oksigen untuk mengoksidasi polutan-polutan organik oleh mikroba secara biokimia menjadi senyawa akhir. Berbeda dengan COD yang menghitung konsumsi oksigen melalui reaksi kimia, sedangkan pada BOD dihitung melalui reaksi biokimia oleh mikroba. Karena keterbatasan mikroba dalam menguraikan polutan organik, maka nilai BOD selalu lebih kecil dari COD. Untuk analisa BOD diperlukan waktu selama 5 hari pada suhu $20^{\circ} \mathrm{C}$, sedangkan untuk mengetahui nilai COD hanya dibutuhkan waktu beberapa jam saja. Nilai BOD air limbah Pasaraya Blok M adalah 103 mg/l. Seperti polutan-polutan yang lain, pada Gambar 19 juga 
dapat dilihat, efisiensi pengurangan BOD juga bisa dipertahankan tetap tinggi selama penelitian berlangsung dari bulan Januari sampai Desember 2017, yaitu di atas $90 \%$. Konsentrasi BOD dalam air olahan selalu rendah, di bawah $8 \mathrm{mg} / \mathrm{l}$. Baku Mutu BOD pada air limbah domestik sebesar $50 \mathrm{mg} / \mathrm{l}$ (Tabel 1).

\section{g. Swapantau dan Analisa Berkala}

Swapantau atau melakukan pemantauan terhadap beroperasinya IPAL adalah hal yang sangat penting (Nugroho, R. dkk., 2013). Dari swapantau akan dapat segera diketahui sekiranya timbul masalah pada operasional IPAL. IPAL Pasaraya Blok $M$ telah melakukan kegiatan swapantau. Hal-hal dipantau antara lain mengukur $\mathrm{pH}$ air pada bak-bak IPAL, pencatatan tekanan udara blower dan pencatatan flow meter air untuk menghitung jumlah air limbah. Di samping pengamatan dan pencatatan langsung, setiap bulan air hasil olahan IPAL juga dinalisa di laboratorium yang terakreditasi. Hasil-hasil pemantauan dan analisa, secara berkala dilaporkan ke Badan Pengelola Lingkungan Hidup Daerah (sekarang Dinas Lingkungan Hidup) Propinsi DKI Jakarta.

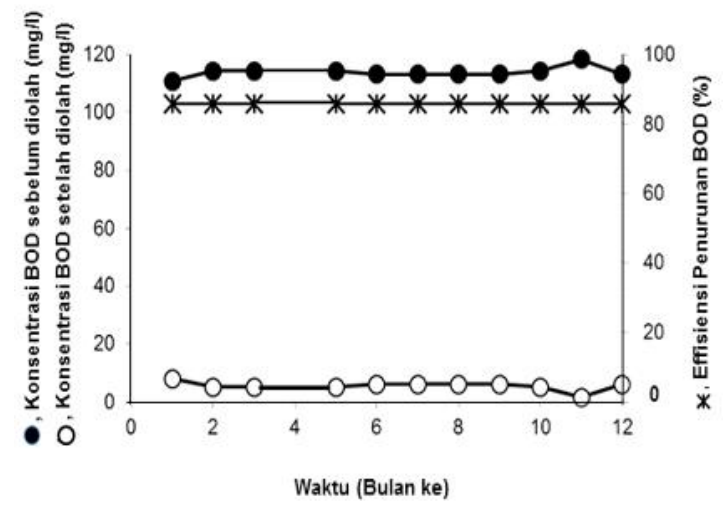

Gambar 19 : Konsentrasi BOD Sebelum dan Setelah Diolah serta Efisensi Penurunan BOD.
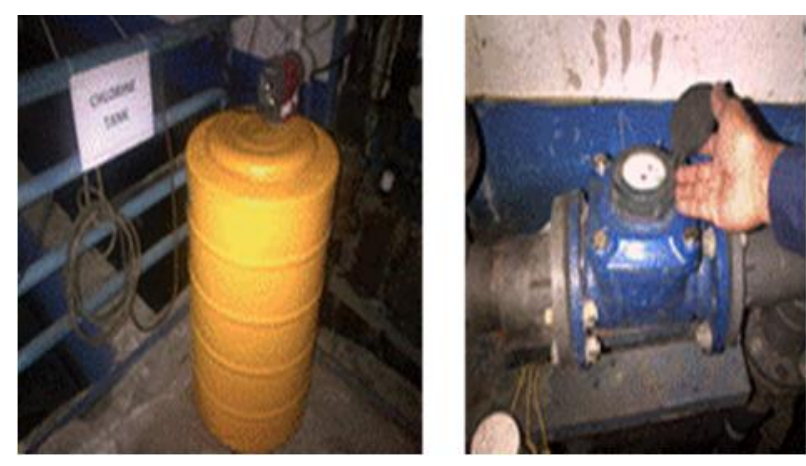

Gambar 20 : Tangki Chlorinasi (kiri) dan Flow Meter (kanan).

\section{IZIN PEMBUANGAN LIMBAH CAIR (IPLC)}

Izin Pembuangan Limbah Cair (IPLC), sekarang namanya diganti dengan Izin Pembuangan Air Limbah adalah salah satu persyaratan yang harus dimiliki oleh kegiatan usaha yang menghasilkan air limbah. IPLC dikeluarkan oleh Gubernur melalui Badan Pelayanan Terpadu Satu Pintu (BPTSP). Persyaratan untuk mendapatkan IPLC adalah unit usaha sudah memiliki IPAL yang baik dan dalam waktu 3 bulan berturut-turut air hasil olahan IPAL memenuhi baku mutu yang ditetapkan.

Berkenaan dengan IPLC, IPAL Pasaraya Blok $M$ sudah memiliki Sertifikat IPLC dengan Nomor Registrasi, No. 91/7.8/31/-1.774.15/2016, yang diterbitkan pada tanggal 25 Oktober 2016. Tabel 3 adalah hasil analisa kualitas air olahan IPAL Pasaraya Blok $\mathrm{M}$ pada saat dilakukan pengajuan IPLC. Di sini terlihat, konsentrasi semua parameter yang persyaratkan sangat rendah, jauh dibawah baku mutu yang ditentukan untuk air limbah domestik (Tabel 1).

Tabel 3 : Hasil Analisa Kualitas Air Olahan IPAL Pasaraya Blok M untuk IPLC.

\begin{tabular}{clcc}
\hline No. & Parameter & Satuan & Besaran \\
\hline 1. & $\mathrm{pH}$ & $(-)$ & 7,2 \\
2. & $\mathrm{KMnO}_{4}$ & $(\mathrm{mg} / \mathrm{l})$ & 2,38 \\
3. & $\mathrm{TSS}$ & $(\mathrm{mg} / \mathrm{l})$ & 3,0 \\
4. & Amonia $\left(\mathrm{NH}_{3}-\mathrm{N}\right)$ & $(\mathrm{mg} / \mathrm{l})$ & 2,03 \\
5. & Minyak dan lemak & $(\mathrm{mg} / \mathrm{l})$ & $<1,13$ \\
6. & Deterjen (MBAS) & $(\mathrm{mg} / \mathrm{l})$ & $<0,03$ \\
7. & COD & $(\mathrm{mg} /)$ & $<40$ \\
8. & BOD & $(\mathrm{mg} /)$ & 1,93 \\
\hline
\end{tabular}

\section{KESIMPULAN}

Dari hasil penelitian yang telah dilakukan dan uraian diatas, dapat disimpulkan beberapa hal sebagai berikut:

- Modifikasi sistem IPAL Pasaraya Blok M menjadi kombinasi lumpur aktif dan biofilter aerob memberikan hasil yang sangat signifikan. Selama lebih dari 1 tahun IPAL beroperasi, efisiensi pengurangan polutan organik selalu tinggi, konsentrasi polutan di dalam air olahan jauh di bawah baku mutu yang ditetapkan

- Perawatan IPAL baru juga mudah dilakukan dan hampir tidak ada kendala yang dihadapi selama kegiatan pengoperasian IPAL.

- IPAL Pasaraya Blok M sudah memiliki Sertifikat Izin Pembuangan Limbah Cair (IPLC), sebagai syarat untuk dapat membuang air olahan IPAL ke badan penerima air. 


\section{UCAPAN TERIMA KASIH}

Pada kesempatan ini, penulis mengucapkan terima kasih kepada bapak Arifiyanto, selaku Building Manager Pasaraya Blok $\mathrm{M}$, atas izin yang diberikan untuk mempublikasikan hasil-hasil operasional dan kinerja IPAL Pasaraya Blok M.

\section{DAFTAR PUSTAKA}

- Ikbal 2013, “Pengelolaan Lingkungan Industri Kecil dalam Rangka Mewujudkan Green City". Prosiding Diseminasi Teknologi Lingkungan. Pusat Teknologi Lingkungan, BPPT.

- Dinas Pekerjaan Umum Provinsi DKI Jakarta 1990. The Study On Urban Drainage And Waste Water Disposal Project In The City Of Jakarta .

- Peraturan Gubernur DKI Jakarta, No 122 tahun 2005, tentang Pengolahan Air Limbah Domestik di Wilayah Propinsi Daerah Khusus Ibukota Jakarta,.

- $\quad$ Setiyono, dkk. 2012, Buku Panduan Operasional IPAL Domestik Gedung PT. Indosat. Tbk.. Pusat Teknologi Lingkungan, BPPT.

- Ikbal, dkk. 2013, Buku Panduan Operasional IPAL Domestik Gedung Kantor Sophie Paris, Jakarta. Pusat Teknologi Lingkungan, BPPT.

- $\quad$ Grady, C.P.L, dkk. 1980, Wastewater Treatment. Marcel Dekker Inc. New York.

- Rittman, B. E. dkk. 2001, Environmental Biotechnology Principles and Applications. Boston, Mc Graw Hill..
- Ikbal, dkk. 1994, Liquefaction and and gasification during anaerobic digestion of coffee waste by two-phase methane fermentation with slurry-state liquefaction. J. Ferment. Bioeng., 77, 85 89,.

- $\quad$ Kida. K., dkk. 1995, Treatment of sewage sludge by two-series digestion with liquefaction of thickened surplus sludge. J. Water Environment (Mizu Kankyou Gakkaishi), 18, 215-221.

- Mc Carty, P.L 1982, One hundred years of anaerobic traetment, Elsevier Biomedical Press B.V., Amsterdam,

- Nagai, S., dkk. 1989, Biological aspects of anaerobic digestion. Handbook of Heat and Mass Transfer, 3, 702-704, Catalysis, Kinetics and Reactor Engineering, Gulf Publishing Co..

- $\quad$ Kida. K, dkk. 1991, Influent of mineral nutrients on high performance during anaerobic treatment of wastewater from beer brewery. J. Ferment. Bioeng. 72, 54-5,.

- $\quad$ Kida, K., dkk. 2001, Influence of $\mathrm{Ni2}+$ and $\mathrm{Co} 2+$ on methanogenic activity and the amounts of coenzymes involved in methanogenesis. J. Biosci. Bioeng., 91, 590-595.

- $\quad$ Said, N. I. 1995, Sistem Pengolahan Air Limbah Rumah Tangga Skala Individual Tangki Septik Filter Up Flow. Majalah Analisis Sistem Nomor 3, Tahun II.

- Nugroho, R. dkk. 2013, Buku Panduan Operasional IPAL Rumah Sakit Universitas Kristen Indonesia. Pusat Teknologi Lingkungan, BPPT. 
